\title{
Analysis of Control of Costs and Time with Earned Value Method on Road Maintenance Projects in Palmerah District, West Jakarta
}

\author{
Sandy Radhitya Akbar ${ }^{*}$, Asep Setiawan, M. Rozahi Istambul, Raden Herdian Bayu Ash Siddiq \\ Department of Civil Engineering, Faculty of Engineering, Widyatama University, Bandung, East Java, Indonesia
}

Copyright $@ 2019$ by authors, all rights reserved. Authors agree that this article remains permanently open access under the terms of the Creative Commons Attribution License 4.0 International License

\begin{abstract}
Control in a construction project generally involves three main aspects, namely: cost, time and human resources. This study uses Network Planning analysis as a control function with the Critical Path Method (CPM) method in calculating the difference in cost and time needed to complete the work with a planned budget and schedule. This study also tried to implement an integrated control function, namely the Earned Value Method for a construction project. Based on the analysis and calculation in the 8th week (eight) of the total duration of the project, the analysis produces CPI value $=1.06$ which shows that the performance of contractor's expenditure costs is more efficient than the planned budget. The description of the final condition of the project also shows that there is a residual budget value of $\mathrm{Rp} 321,642,608.01$ or $5.55 \%$ of the total value of the overall project cost budget or Budgeted At Completion (BAC) which is an advantage for the contractor. The analysis also produces SPI value $=0.94$ which means that the time performance index is of good value but the execution of the work is a little slower than the overall planned schedule.
\end{abstract}

Keywords Critical Path Method, Earned Value Method, Metode Nilai Hasil, ACWP, BCWP, BCWS, BAC, CPM

\section{Introduction}

Project resources, especially construction projects, consist of material, labor, funding, implementation methods and equipment. These resources are planned to achieve project targets with time, cost and quality limits. The challenge in implementing a construction project is how to plan an effective time schedule and efficient cost planning without reducing the quality of the work itself. In order to fulfill this, the construction project must be professionally processed with good and weighty project management.

The success or failure of a construction project is determined by the managerial policies taken. Therefore, in a construction project, managerial skills are needed starting from a good planning process and actions related to the function of supervision and control of costs, schedules and the quality of the work carried out. These three things are interconnected and are closely related to each other and must be carried out at the same time along with the ongoing implementation of the project.

Construction project management takes place like a repetitive cycle consisting of planning, implementing, evaluating and following up. At the planning stage, a plan is made to carry out a construction project with the limitations of cost, schedule and quality as planned. At the implementation stage, supervision and control is needed to keep it in line with planning.

Control is one of the management functions of the construction project which aims to make the work run well and achieve the goals and successes that have been planned without many deviations.

The progress of a construction project can be measured by comparing the work plan that has been compiled from the beginning to the completion of the project, with the progress of the work achieved in a certain period of time during the project. The description above shows that an integrated and comprehensive analysis of the Cost and Schedule needs to be done to avoid irregularities.

The objectives of this research are:

1. Apply the Earned Value analysis method to the costs and time in the Road Maintenance Project in Palmerah District, West Jakarta.

2. Review the productivity index and performance of the project by reviewing the cost and time performance index.

3. Conduct forecasting by estimating the project schedule and final costs in completing the construction project. 


\section{Literature Review}

The process of achieving the project objectives is a limitation that must be met, namely the amount of costs or budget allocated, time schedule, and certain quality specifications. These three things are important parameters for project organizers. The three limits above are also called Triple Constructions: Project Cost Budget, Project Schedule and Project Quality or Quality.

Technically, the measure of the success of a project will be related to the extent to which the three objectives can be met. The three targets are closely related and are of an interest. This means that if you want to improve the production performance that has been planned, generally it must be followed by improving the quality of work. This will then result in an increase in costs so that it exceeds the budget. Conversely if you want to reduce costs, then you usually have to compromise with the quality and schedule of the project.

Control System Implementation of a construction project requires Cost Control, Time Control and Quality Control, with the aim that the implementation of the project can run according to the target as planned. Control requires standards or benchmarks as comparison, performance measurement tools, and corrective actions carried out immediately in the event of irregularities.

The basic concept of results value can be used in performing performance analysis and making forecast estimates. The indicators used by this method are:

1. The BCWS (Budgeted Cost of Work Schedule) is the cost budget provided based on a work plan prepared against the schedule and is the plan $\mathrm{S}$ curve.

2. BCWP (Budgeted Cost of Work Performed) is the value received from the completion of the work for a certain period of time. This BCWP is called Earned Value, which is calculated based on the accumulation of completed work. BCWP is often referred to as the actual S curve.

3. ACWP (Actual Cost of Work Performed) is the amount of actual costs of work that has been completed in a certain period of time. ACWP is the actual amount of expenses or funds used to carry out the work of a project for a certain period of time.

\section{Project Performance Assessment with Earned Value Method}

The use of the Earned Value method in carrying out the analysis includes the following elements:

\section{a. Cost Variance}

Cost Variance or CV (Cost Variance) is the difference in value obtained after completing a job with the actual cost of implementing the project for a certain period of time.

Cost Variance is calculated using the following formula:

$$
\mathrm{CV}=\mathrm{BCWP}-\mathrm{ACWP}
$$

\section{b. Schedule Variance}

Schedule Variance or SV (Schedule Variance) is the difference between achievement and progress of work (progress) with the target of the work at that time.

Schedule variance is calculated by the formula:

$$
\mathrm{SV}=\mathrm{BCWP}-\mathrm{BCWS}
$$

\section{c. Cost Performance Index}

Cost Performance Index or CPI (Cost Performance Index) is a comparison of the value received from the completion of a physical work with the actual costs incurred to complete the work.

The cost performance index is calculated by the formula:

$$
\mathrm{CPI}=\mathrm{BCWP} / \mathrm{ACWP}
$$

The CPI value shows the weight of the relative value obtained from the overall project value with the costs incurred. CPI values greater than $1(>1)$ indicate good cost performance because there is an actual cost savings in implementation when compared to the planned cost for the work. While the CPI value of less than $1(<1)$ shows a poor cost performance because the actual cost incurred (ACWP) is greater than the value of the work completed (BCWP), or in other words waste has occurred.

\section{d. Time Performance Index}

Time Performance Index or SPI (Schedule Performance Index) which is a comparison between the completion of work in the field with a work plan for a certain period of time.

The formula for calculating the time performance index is:

$$
\mathrm{SPI}=\mathrm{BCWP} / \mathrm{BCWS}
$$

The SPI value greater than $1(>1)$ shows a good cost performance because the work completed exceeds the previously planned target.

\section{Method}

The method in this study is descriptive, namely the method used to find elements, characteristics, traits of a phenomenon. The implementation of this method is generally through: survey techniques, case studies, comparative studies, studies of time and motion, behavior analysis, and documentary analysis.

\section{Stages of Research}

The stages in the research are sequential and systematic steps in accordance with the theoretical basis of the 
research problem so that an accurate analysis can be obtained to achieve the research objectives and objectives.

The work steps in the form of stages in this study can be explained by the following descriptions:

\section{a. Preliminary Studies}

The preliminary study is the initial stage to deepen knowledge and strengthen theories related to research topics, namely the evaluation of costs and time by using analysis Earned Value method as a function of supervision and control of a project. Likewise deepening the theory of the Critical Path Method (CPM) in calculating the difference between the time schedule of the plan and the realization of the project completion time.

\section{b. Literature Study}

The preliminary study then continued with the literature study stage or literature study to collect references and conduct studies on guide books, lecture materials, scientific journals, scientific works, and other reference materials.

\section{c. Field Study}

The field study was carried out by observing and directly following the implementation of the Heavy Road Periodic Maintenance Project in the ongoing District of Palmerah West Jakarta 2017. Field studies were also conducted with direct interviews with staff and management of PT. Widya Sapta Colas as the executive contractor for the work project.

\section{d. Data Collection Phase}

The data used in this study are the Budget Plan, the work plan schedule in the form of a Plan S Curve, weekly progress, weekly expenditure reports, project plan drawings, profiles and general description of the project. The data above is obtained from the executive contractor, either directly or through observation and interviews with the staff and management of PT. Widya Sapta Colas as the executive contractor for the project.

\section{e. Analysis and Discussion Phase}

The analysis and discussion phase is carried out in this research is as follows:

1. Analysis and discussion of work planning schedules with the realization of the completion time of work using the Critical Path Method (CPM) method.

2. Calculating the BCWS (Budgeted Cost of Work Schedule) or scheduled work budget based on the plan. BCWS is calculated from the work weight and cost plan.
3. Calculate BCWP (Budgeted Cost of Work Performed) or the value received from the completion of the work for a certain period of time. This BCWP is called Earned Value, which is calculated based on the accumulation of work that has been completed or calculated from the actual weight of all work activities against the value of the project contract.

4. Calculating ACWP (Actual Cost of Work Performed) or the actual amount of work that has been completed in a certain period of time. ACWP is calculated from the total direct costs, indirect costs, and other actual expenses.

5. Calculating Cost Variance, which is calculated from the difference in BCWP value with ACWP, and calculating Schedule Variance or SV (Schedule Variance) which is the differences between the BCWP value and BCWS.

6. Calculating the Cost Performance Index from the comparison of BCWP values with ACWP, and calculating the Time Performance Index or SPI (Schedule Performance Index) by comparing the BCWP value with BCWS.

7. Calculate the Prediction of Project Final Settlement Cost (EAC (Estimate At Completion) from the total value of ACWP and ETC, and calculate the Cost Prediction for Remaining Work or ETC (Estimate To Completion) of the budgeted cost to complete the entire project work or BAC (Budgeted At Completion) which is reduced by the BCWP value, and then divided by the CPI value.

8. Describe the results of the calculations above in a relationship graph. At this stage there is also a discussion which is a form of explanation of the calculations that have been done and presents the results of the analysis in a graph.

\section{f. Stage of Conclusions and Suggestions}

At this stage, the data that has been through the analysis and discussion phase will be drawn into a line of conclusions in response to the problems formulated in the study. The suggestions given relate to the results of research that illustrates practical uses (follow-up) of the implications of research results as an axiological dimension of science. These suggestions must be based on conclusions as a result of a study.

\section{Findings}

\section{Project General Data}

The general project data reviewed in this study are as follows: 


\begin{tabular}{ccl}
\hline 1. & The project name: & Road Maintenance Project in Palmerah Subdistrict, West Jakarta \\
\hline \multirow{2}{*}{ 2. } & Organisasi/ SKPD: & 3.05.04.00.0000.00 \\
\cline { 3 - 3 } & Suku Dinas Bina Marga Jakarta Barat \\
\hline 3. & Kode Rekening: & 5.2.2.20.01.006 Belanja Pemeliharaan Jalan Provinsi \\
\hline
\end{tabular}

\section{b. Budget Plan (RAB)}

The budget for the Heavyweight Road Maintenance Project in Palmerah District in 2017 is:

Table 1. Budget Plan (RAB)

\begin{tabular}{|c|c|c|c|c|c|}
\hline No & Description Work & Volume (Ton) & Unit price (Rp) & Total price (Rp) & Weight (\%) \\
\hline $\mathrm{a}$ & b & c & d & $e=c x d$ & $\mathrm{f}$ \\
\hline \multicolumn{6}{|c|}{ DIVISI VI PERKERASAN ASPAL } \\
\hline s.s & $\begin{array}{l}\text { Laston AC-WC (installed) and includes asphalt } \\
\text { emulsion for Tack Coat (m2) price per Ton }\end{array}$ & 4188,19 & $1.190 .909,09$ & 4.987.753.545,45 & 86,06 \\
\hline S.S & $\begin{array}{l}\text { Laston AC-BC (installed) and includes asphalt } \\
\text { emulsion for Tack Coat (m2) per Ton price }\end{array}$ & 710,94 & $1.136 .363,64$ & 807.886.363,64 & 13,94 \\
\hline \multicolumn{4}{|c|}{ Sub Total } & $5.795 .639 .909,09$ & 100,00 \\
\hline \multicolumn{4}{|c|}{ PPN $10 \%$} & 579.563.990,91 & \\
\hline \multicolumn{4}{|c|}{ Total Jumlah } & 6.375.203.900,00 & \\
\hline
\end{tabular}

Source: Data General Affair (GA) PT. WASCO - DKI 2017

Based on table 1 the project cost budget plan is Rp. 5,795,639,909.09 (five billion seven hundred ninety five million six hundred thirty nine thousand nine hundred nine rupiahs). Plus VAT (Value Added Tax) of $10 \%$, namely Rp. 579,563,990.91 (five hundred seventy nine million five hundred sixty three thousand nine hundred ninety rupiah). The total value of the project in accordance with the contract is Rp. 6,375,203,900.00 (six billion three hundred seventy five million two hundred three thousand nine hundred rupiah).

\section{c. Work Implementation Plan}

Plans for the execution of work in this study as shown in the following table:

Table 2. Work Implementation Plans

\begin{tabular}{|c|c|c|c|}
\hline \multirow{2}{*}{ No. } & \multirow{2}{*}{ Period } & \multicolumn{2}{|c|}{ Job load (\%) } \\
\cline { 3 - 4 } & & Individual & Cumulative \\
\hline 1 & $18-$ 24 June 2017 & - & 0,000 \\
\hline 2 & $25-$ 01 July 2017 & 3,463 & 3,463 \\
\hline 3 & 02 - 08 July 2017 & 15,671 & 19,134 \\
\hline 4 & 09 - 15 July 2017 & - & 19,134 \\
\hline 5 & $16-22$ July 2017 & - & 19,134 \\
\hline 6 & $23-$ 29 July 2017 & 10,040 & 29,174 \\
\hline 7 & 30 - 05 August 2017 & 18,106 & 47,280 \\
\hline 8 & $06-12$ August 2017 & 19,556 & 66,836 \\
\hline 9 & $13-19$ August 2017 & 17,736 & 84,572 \\
\hline 10 & $20-26$ August 2017 & 15,427 & 100,000 \\
\hline 11 & 27 - 31 August 2017 & - & 100,000 \\
\hline
\end{tabular}

Sumber: Data General Affair (GA) PT. WASCO - DKI 2017

\section{d. Job Progress Report}

Work progress reports are as follows:
Table 3. Weekly Progress Reports

\begin{tabular}{|c|c|c|c|}
\hline \multirow{2}{*}{ No. } & \multirow{2}{*}{ Period } & \multicolumn{2}{|c|}{ Job Load (\%) } \\
\cline { 3 - 4 } & & Individual & Cumulative \\
\hline 1 & $18-$ 21 June 2017 & - & 0,000 \\
\hline 2 & $22-$ 28 June2017 & - & 0,000 \\
\hline 3 & $29-$ 05 July 2017 & 11,414 & 11,414 \\
\hline 4 & $06-12$ July 2017 & 7,720 & 19,134 \\
\hline 5 & $13-19$ July 2017 & - & 19,134 \\
\hline 6 & 20 - 26 July 2017 & - & 19,134 \\
\hline 7 & 27 - 02 August 2017 & 19,480 & 38,614 \\
\hline 8 & $03-$ 09 August 2017 & 23,951 & 62,565 \\
\hline 9 & $10-16$ August 2017 & 17,532 & 80,097 \\
\hline 10 & $17-23$ August 2017 & 19,903 & 100,000 \\
\hline
\end{tabular}

Sumber: Data General Affair (GA) PT. WASCO - DKI 2017

\section{e. Actual Cost of Work Report}

Reports on actual work costs are as follows:

Table 4. Report on Actual Costs of Work

\begin{tabular}{|c|c|c|c|}
\hline \multirow{2}{*}{ No. } & \multirow{2}{*}{ Period } & \multicolumn{2}{|c|}{ Actual Cost (Rp) } \\
\cline { 3 - 4 } & & Individual & Cumulative \\
\hline 1 & $18-21$ June 2017 & - & 0,00 \\
\hline 2 & $22-28$ June 2017 & - & 0,00 \\
\hline 3 & $29-05$ July 2017 & $624.802 .051,94$ & $624.802 .051,94$ \\
\hline 4 & $06-12$ July 2017 & $422.592 .591,64$ & $1.047 .394 .643,59$ \\
\hline 5 & $13-19$ July 2017 & - & $1.047 .394 .643,59$ \\
\hline 6 & $20-26$ July 2017 & - & $1.047 .394 .643,59$ \\
\hline 7 & $27-02$ August 2017 & $1.066 .340 .148,25$ & $2.113 .734 .791,84$ \\
\hline 8 & $03-09$ August 2017 & $1.311 .077 .093,58$ & $3.424 .811 .885,42$ \\
\hline 9 & $10-16$ August 2017 & $959.684 .784,83$ & $4.384 .496 .670,25$ \\
\hline 10 & $17-23$ August 2017 & $1.089 .506 .630,83$ & $5.473 .997 .301,08$ \\
\hline
\end{tabular}

Source: Data General Affair (GA) PT. WASCO - DKI 2017 


\section{Analysis and Discussion}

The results of data analysis and calculations as well as evaluations carried out in the 8th week (eight) of the project have shown the general description, condition, and final conditions of Road Maintenance Project in the District of Palmerah West Jakarta 2017 as follows:

\section{a. Cost Variance and Cost Performance Index}

Cumulative cost variance results show that the $\mathrm{CV}$ value $=\mathrm{Rp} 201,236,019.35$ and the cost performance index value is CPI $=1.06$. From the results of this analysis and calculation, it can be shown that in the implementation of the Heavy Periodic Road Maintenance Project in the District of Palmerah, West Jakarta in 2017, the implementing contractor obtained cumulative cost variance that was of quite good value. This can also be seen from the results of the cost performance index also shows the CPI value $>1$, which means that the costs incurred are less than the planned cost budget (cost underrun). Saving the cost of work on the field will certainly result in the inclusion of income in the form of profits or profits (profit) for the implementing contractor.

\section{b. Variance Schedule and Time Performance Index}

The time to carry out the project is based on a contract on June 18, 2017. Entering the beginning of the work period for the 1st (first) and 2nd (two) weeks which is referred to as deviation from the planned work schedule. At the same time there is still no work.
The results of the calculation of the cumulative emergency schedule variance value of Rp. 247,554,746.80. The minus value (-) can be done because (BCWP) is smaller or less than the average proven cost (BCWS). Based on the results of the variance schedule (SV) cumulatively until the 8th week (eight) of the results of the work that has been completed (BCWP) by the shipping contractor is still lacking or minus to the overall work schedule planning.

The value of the negative time performance index $(+)$ is equal to SPI $=0.94$. The value of the analysis and the results of the SPI calculation $<1$, this happened in the implementation of the Heavyweight Road Maintenance Project in the District of Palmerah West Jakarta in 2015, the contractor straightened the work a little later than the schedule. One part of the project (BCWS), the project will be carried out within the period of the 1st (first) week, ie 18 - 24 June 2017 to the 11th (eleven) week period, ie 27 - 31 August 2017 completed (BCWP) contractor work carried out in general on the tenth (ten) weekly period, including for a period of 2 (two) weekly periods. Can be received and done very publicly from the schedule that has been entered (schedule is less than that).

\section{c. Graph of Relationship between Work Productivity Indexes}

Based on the results of the analysis of the work productivity index, there is a relationship between the Cost Performance Index (CPI) and the Time Performance Index (SPI), namely:

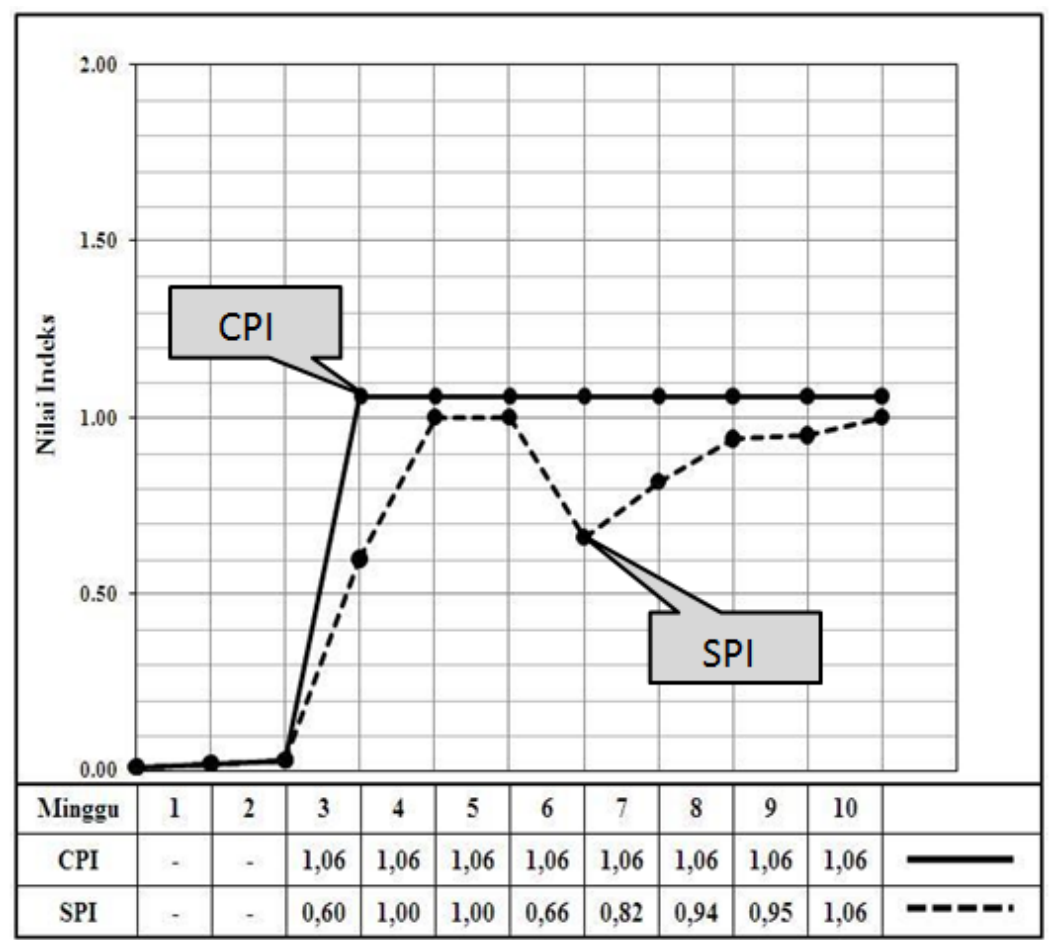

Source: Research Results

Figure 1. Graph of Relationship between Work Productivity Indexes 
The graph above illustrates that the value of the Cost Performance Index (CPI) is controlled, namely CPI $>1$, which means that the cost of work spent is less than the planned budget (cost underrun). While the value of the Time Performance Index (SPI) varies with the schedule deviations that occur, but the overall implementation of the project work is faster than the planned schedule (schedule underrun).

\section{d. Estimated Project Completion Costs and Estimated Time for Project Completion}

The results of the calculation of the estimated cost of project completion costs or Estimate at Completion (EAC) obtained a value of Rp. 5,473,997,301.08. With the estimation of the Estimate at Completion Date (ECD) on the Heavy Road Periodic Maintenance Project in Palmerah District, West Jakarta in 2017, which is 10.88 weeks, the Estimate to Completion (ETC) is still needed in the amount of Rp. 2,049. 185,415.66 to complete the entire project work.

Based on the analysis and calculations carried out using elements of the Earned Value method, it can provide a general description of the project's final condition and condition that there is a remaining work cost budget of Rp. $321,642,608.01$ or $5.55 \%$ of the total budget value. Overall project cost or Budgeted at Completion (BAC).
The remaining budget for the implementation of the work becomes profit or profit for the contractor implementing the Heavyweight Road Maintenance Project in the District of Palmerah West Jakarta in 2017.

\section{e. Project Scheduling Analysis and Identification of Critical Paths}

Table 5. List of Project Activities in Critical Pathways

\begin{tabular}{|c|c|c|c|}
\hline NO & NAME OF ACTIVITY & DURATION & CODE \\
\hline 1 & PCM (Pre Construction Meeting) & 1 & A $(1,2)$ \\
\hline 2 & Preparation & 2 & B $(2,3)$ \\
\hline 3 & Cleaning Site & 1 & D (3,5) \\
\hline 4 & Overlay AC-WC & 45 & F (5,6) \\
\hline 5 & Demobilization & 1 & $\mathrm{G}(6,7)$ \\
\hline 6 & Finish & 1 & $\mathrm{H}(7,8)$ \\
\hline
\end{tabular}

Source: Research Results

All activities or work activities cannot be postponed in the process, because if a delay is made in the work activities mentioned above it will result in a delay in the overall completion of the project work.

The duration of time for the implementation of the Heavyweight Road Maintenance Project in the District of Palmerah West Jakarta in 2017 can be seen in the table below:

Table 6. Comparison of Duration of Work Implementation Time

\begin{tabular}{|c|l|c|c|c|}
\hline \multirow{2}{*}{ No. } & \multicolumn{1}{|c|}{ DESKRIPSI } & \multicolumn{2}{c|}{ DURATION } \\
\cline { 3 - 5 } & & Day & Week & Weekly \\
\hline 1 & Appropriate Implementation Time Employment contract & 60 & 8 & 8 \\
\hline 2 & Appropriate Implementation Time Planning Schedule & 75 & 10,71 & 11 \\
\hline 3 & Estimated Time for Project Completion & 76,16 & 10,88 & 11 \\
\hline 4 & Appropriate Implementation Time Actual Realization & 67 & 9,57 & 10 \\
\hline 5 & $\begin{array}{l}\text { Appropriate Implementation Time Analysis of the CPM } \\
\text { Method }\end{array}$ & 52 & 7,43 & 8 \\
\hline
\end{tabular}

Source: Company Data and Research Results 
Based on table 6 above can be seen the difference in duration of planned work execution time when compared to the implementation time according to realization there is an acceleration of 8 (eight days). Likewise, the results of the time scheduling calculation are performed using the CPM method (Critical Path Method) to increase efficiency and save 15 (fifteen) days when compared to the implementation time according to the realization to complete the entire project work.

\section{f. Comparative Analysis of BCWS, BCWP, and ACWP}

Comparison of scheduled work budgets (BCWS), implemented work budgets (BCWP), and actual work realization costs (ACWP) can be displayed graphically as shown below:

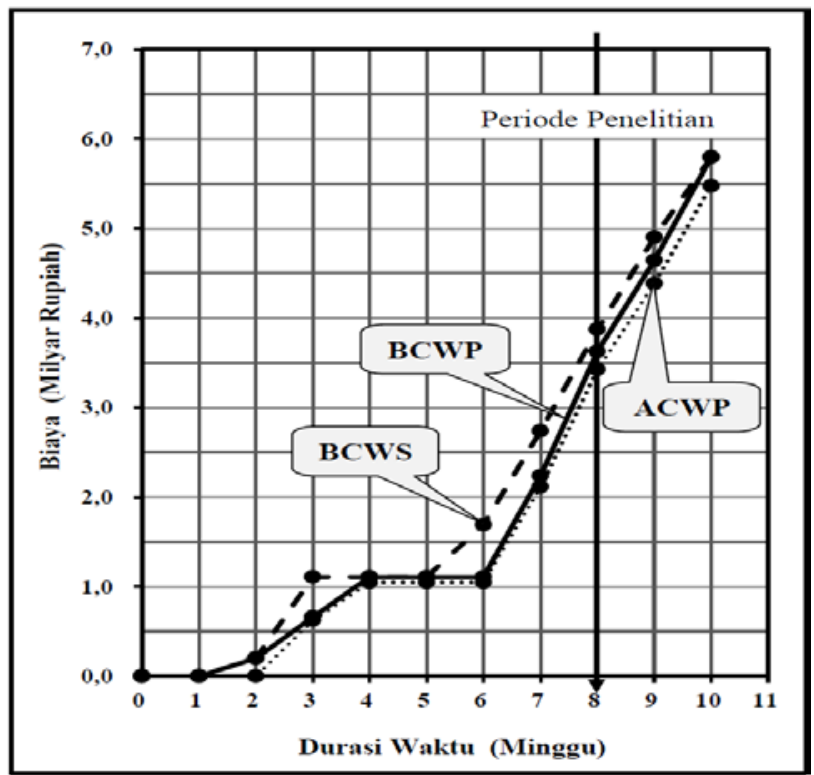

Source: Company Data and Research Results

Figure 2. Graph Analysis of BCWS, BCWP, and ACWP

Based on the graph in Figure 2 it can be seen the relationship of BCWS, BCWP, and ACWP. The relationship between the three graphs can be explained as follows:

\section{a. Comparison of BCWS and BCWP charts}

From the graph, it can be seen that the BCWP chart line is more often under BCWS and then meets at the end point. This can indicate that a lot of the planned work can be completed with less cost (cost underrun) but in the planning schedule (time schedule) there are still delays in some periods so it must accumulate and must be pursued in the next time period even though the overall implementation of the work quite efficient and faster than the planned schedule (schedule underrun).

\section{b. Comparison of BCWS and ACWP charts}

In the graph above shows that the ACWP chart line is below the BCWS graph, which means that the cumulative value of the actual costs incurred is controlled and less than the planned cost (cost underrun).

\section{c. Comparison of BCWP and ACWP charts}

The ACWP chart is slightly below the BCWP graph, which means the cumulative value of actual costs is less than the cost that should have been incurred. In this case the project is shown with a positive value $(+)$ and will benefit the contractor.

\section{Conclusions}

Based on the results of data processing by conducting analysis and calculation as a whole, the discussion of research on Road Maintenance Project in the District of Palmerah West Jakarta in 2017 has been able to provide some conclusions in the effort to apply the analysis of Earned Value method as one of the monitoring functions and control of the project. The general conclusions referred to include the following:

1. Cost Performance Index (CPI) The results of research on the cost performance index have concluded, namely:

(1) Value of the Cost Performance Index based on analysis and calculation on the duration of the 8th week work (eight) of CPI $=1.06$ and cumulatively at 4.24. This shows that in the implementation of the Heavyweight Road Maintenance Project in the District of Palmerah West Jakarta in 2017, the contractor gets the results of a cost variance that is of good value. The results of the analysis of the cost performance index also shows the CPI value> 1 , which means that the contractor's expenditure costs are smaller than the planned cost budget (cost underrun). The actual cost savings of the implementation of work or Actual Cost can reduce the deviations that may occur in the field.

(2) The results of the calculation of the estimated value of project completion costs or Estimate at Completion (EAC) are Rp. 5,473,997,301.08. With an estimated completion time of the project or Estimate at Completion Date (ECD) of 10, 88 weeks or 11 weekly periods, the Estimate to Completion (ETC) costs Rp 2,049,185,415.66 will be required to complete the entire work package project.

(3) Analysis and calculations carried out using elements of the Earned Value method can provide a general description of the project's final condition and condition that there is a remaining work cost budget of Rp. 321,642,608.01 or 5.55\% of the total value of the overall project cost budget or Budgeted at Completion (BAC). The remaining budget for the implementation of the work becomes a profit or profit for the contractor implementing the 
Heavyweight Road Maintenance Project in the District of Palmerah West Jakarta in 2017.

2. Time Performance Index (SPI)

Some conclusions of the results of research regarding the time performance index are:

(1) The value of the Time Performance Index based on analysis and calculation on the duration of the 8th week work (eight) is SPI = 1.22 and cumulatively is 3.03. This shows that in the implementation of the Heavyweight Road Maintenance Project in the District of Palmerah, West Jakarta, in 2017, the contractor obtained a time variance that was of quite good value. SPI value $>1$, which means that the implementing contractor can complete the work earlier than the planned schedule (schedule underrun).

(2) Based on the results of the variance value of the schedule and the time performance index, the estimated time of project completion or Estimate at Completion Date $(\mathrm{ECD})=10.88$ weeks or 11 (eleven) weekly periods. A shift in the work implementation plan from the duration of the contract for 60 (sixty) calendar days or 8 (eight) weekly periods to 75 (seventy five) days or 10.71 weeks or 11 (eleven) weekly periods, because it coincides with time off and joint leave Idul Fitri $1438 \mathrm{H} / 2017$.

3. The application of the analysis of Earned Value method as one of the functions of supervision and control of the Heavyweight Road Maintenance Project in the District of Palmerah West Jakarta in 2017 can be done, because the implementing contractor already has a fairly neat administrative system so that supporting data as elements of analysis the method is quite easy to obtain and collect.

4. The main obstacle in implementing the analysis of the Earned Value method in the Heavyweight Road Maintenance Project in the District of Palmerah West Jakarta in 2017 is that there are still certain data and documents that cannot be accessed because they are classified as a form of company policy.

5. Efforts to apply the Earned Value method analysis can be carried out in other business fields, but the completeness of supporting data as an element of analysis must be further reproduced.

6. There is a difference in the planned implementation time when compared to the implementation time according to the realization there is an acceleration of 8 (eight days). While the results of the scheduling analysis carried out using the CPM method (Critical Path Method) increases efficiency and saves 15 (fifteen) days when compared to the implementation time according to the realization in completing the entire project work.

\section{REFERENCES}

[1] Rabiei, S. P., \& Azarafza, R. (2014). Investigate of Mechanical Fuse in Cardan Shaft Using FEM. Review of Information Engineering and Applications, 1(1), 1-10.

[2] Efendi, Ersan, "Controlling Time and Cost Using the PERT Method in the Tanjungjati B PLTU Project Unit 3 and 4 in Jepara Regency", Thesis, Civil Engineering Study Program, Faculty of Engineering, Muhamadiyah University Surakarta, 2014.

[3] Ervianto, I. W., "Construction Project Management", ANDI, Yogyakarta, 2013.

[4] Heruddin, "Control of Cost and Time with the Concept of Value Result in the Project of Shaft and Rainwater Road Construction Works in Matakali and Monomulyo Districts, Polman District", Thesis, Department of Civil Engineering, Faculty of Engineering, Hasanuddin University, 2014.

[5] Husen, Abrar, "Project Management", Revised Edition, ANDI, Yogyakarta, 2010.

[6] Karaini, Armaini A., "Introduction to Project Management", Issue 1, Print 2, Dictate Series Lecture, Gunadarma University, Jakarta, 1994.

[7] Project Management Institute, "A Guide to the Project Management Body of Knowledge: PMBOK Guide", 3rd Edition, PMI Publications, Pennsylvania, United State of America (USA), 2004.

[8] Soeharto, Faith, "Project Management: From Conceptual to Operational", Issue 2, Mold 1, Erlangga, Jakarta, 1999.

[9] Subiyanto, Ibnu, "Research Methodology", Lecture Dictate Series, Gunadarma University, Jakarta, 1993.

[10] Mohamed, A. A., Abouzied, A. S., \& Hamed, F. I. (2017). Synthesis and Cytotoxicity of Thiophene, Thieno [2, 3-C] Pyrazole, Thieno [2, 3-D] Pyrimidine and Pyridine Derivatives Derived from 2-Acetylfuran. International Journal of Chemistry and Materials Research, 5(1), 1-14.

[11] Adedeji, K. A., Yussouff, A. A., Adebanjo, S. A., \& Raji, W. A. (2017). Production Processing for the Beneficiation of Waste Polythylene Product. International Journal of Chemical and Process Engineering Research, 4(1), 13-24.

[12] Widiasanti, Irika and Lenggogeni, "Construction Management", PT Remaja Rosdakarya, Bandung, 2013. 